JOEAI (Journal of Education and Instruction)

Volume 2, Nomor 2, Desember 2019

e-ISSN : 2614-8617

p-ISSN : 2620-7346

DOI: https://doi.org/10.31539/joeai.v2i2.894

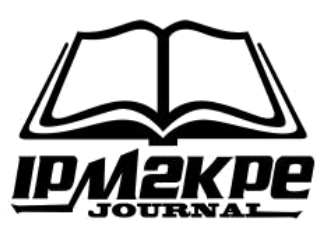

\title{
INOVASI PEMBELAJARAN PENDIDIKAN AGAMA ISLAM (PAI) BERBASIS TEKNOLOGI INFORMASI
}

\author{
Asmara Yumarni \\ Universitas Prof. Dr. Hazairin, SH Bengkulu \\ asmara27yumarni@gmail.com
}

\begin{abstract}
ABSTRAK
Tujuan penelitian ini untuk melihat inovasi pembelajaran Pendidikan Agama Islam (PAI) di Universitas Prof. Dr. Hazairin, SH Bengkulu berbasis teknologi informasi guna mempermudah proses pembelajaran PAI. Metode penelitian yang digunakan adalah metode kualitatif. Data primer diambil dari wawancara dan observasi, dan data sekunder diambil dari dokumentasi. Analisis data menggunakan teknik kualitatif deskriptif. Hasil penelitian didapatkan dua tema, pertama, kebijakan mata kuliah pendidikan agama islam di Unihaz mengacu kepada undang-undang tentang pendidikan tinggi yang mengukuhkan wajib adanya mata kuliah pendidikan agama. Kedua, inovasi yang dilakukan dalam pembelajaran pendidikan Islam berbasis teknologi informasi adalah; 1) Diinstruksikan menggunakan jurnal-jurnal online atau media internet sebagai sumber mencari tugas, 2) Tugas dibuat dalam bentuk video, 3) Pembagian tugas dan Pengumpulan tugas melalui e-mail dan WhatsApp. Simpulan, Mata Kuliah Pendidikan Agama adalah mata kuliah wajib nasional dengan capaian pembelajaran terbentuknya kepribadian mahasiswa secara utuh (kaffah), inovasi pendidikan yang dilakukan di Unihaz yang dominan adalah Devolopment (Pengembangan) pembaharuan yang biasanya harus mengalami suatu pengembangan, dan belum bisa masuk ke dalam dimensi skala besar, Inovasi dilakukan untuk dapat memecahkan masalah-masalah kependidikan. Simpulan, penggunaan teknologi informasi dalam inovasi pembelajaran PAI di PTU harus dikembangkan dan ditempatkan menjadi sumber bahan ajar, referensi belajar, dan sumber informasi
\end{abstract}

Kata Kunci: Inovasi Pembelajaran, Teknologi Informasi, Pendidikan Agama Islam (PAI).

\begin{abstract}
The purpose of this study was to look at innovations in learning Islamic Education (PAI) at Prof. University. Dr. Hazairin, SH Bengkulu based on information technology in order to facilitate the learning process of PAI. The research method used is a qualitative method. Primary data is taken from interviews and observations, and secondary data is taken from documentation. Data analysis uses descriptive qualitative techniques. The results of the study found two themes, first, the policy of Islamic religious education courses in Unihaz refers to the law on higher education which confirms the existence of religious education courses. Secondly, innovations made in the learning of information technology-based
\end{abstract}


Islamic education are; 1) Instructed using online journals or internet media as a source of searching for assignments, 2) Tasks made in the form of videos, 3) Division of tasks and Collection of tasks via e-mail and WhatsApp. In conclusion, the Religious Education Course is a national compulsory subject with the achievement of learning the formation of a whole student personality (kaffah), educational innovation carried out at Unihaz which is dominant is the Devolopment (Development) renewal which usually must undergo a development, and cannot be entered into large-scale dimension, Innovation is done to be able to solve educational problems. Conclusion, the use of information technology in PAI learning innovation at PTU must be developed and placed as a source of teaching materials, learning references, and information sources

Keywords: Learning Innovation, Information Technology, Islamic Religious Education (PAI)

\section{PENDAHULUAN}

Perkembangan teknologi informasi dan komunikasi telah membawa perubahan besar dalam berbagai bidang kehidupan, tidak terkecuali dalam dunia pendidikan. Pengamatan sederhana menggambarkan dinamika prilaku dan kecenderungan peminat generasi milenial ini saat berinteraksi dengan dunia internet dalam kaitannya dengan dunia pendidikan. Mereka lebih menyenangi informasi berbasis visual (melalui Youtube, online games) ketimbang melalui narasi dan teks-teks (membaca buku cetak/bahan ajar atau mendengar dosen menyampaikan materi).

Mereka piawai berselancar dan bereksplorasi di dunia maya, menerima dan mengkurasi informasi ketimbang pasif terperangkap di perpustakaan konvensional. Mereka lebih nyaman untuk belajar secara kolaboratif di dalam praktik nyata atau secara peer to peer melalui jejaring sosial (menggunakan social learning platform) dan mereka lebih suka menggunakan interactive gaming (gamifikasi).

Ketika mahasiswa kita sudah berubah maka pendidikan juga akan terkena dampak disrupsi yang merugikan anak-anak kita. Teramat banyak berita dan informasi yang menjelaskan bahwa social learning platform memang memberikan banyak manfaat, tak hanya menjadi media untuk berkomunikasi namun juga menjadi sarana untuk mendapatkan beragam informasi terbaru dan terupdate. Fenomena-fenomena tersebut menarik untuk dibicarakan.

Perkembangan teknologi dan informasi nyatanya sudah tidak bisa dihindari, tinggal bagaimana pendidikan merespon dan mengantisipasi masalah tersebut? Apa lagi kalau kita memetahkandampak kemajuan teknologi informasi terhadap sikap, kepribadian dan perilaku anak-anak kita. Lebih khusus terhadap moralitas, karakter dan keberagaman anak-anak kita selama ini, yang hal tersebut merupakan tanggung jawab pembelajaran Pendidikan Agama Islam (PAI) di perguruan tinggi. 
Tujuan mata kuliah pendidikan agama (PAI) pada perguruan tinggi umum (PTU) merupakan bagian integral dari tujuan pendidikan nasional. Dalam pencapaian tujuan pendidikan tersebut, keberhasilan mata kuliah pendidikan agama islam (PAI) pada perguruan tinggi umum (PTU) dipengaruhi oleh beberapa faktor. Salah satu faktor penting itu adalah proses pembelajaran atau perkuliahan.

Untuk itulah perlu adanya inovasi dalam pembelajaran pendidikan agama islam (PAI), salah satu solusinya adalah dengan pembelajaran berbasis teknologi infomasi, seperti CBT (computer based test), CBI (computer based intstruction), distance liarning, LCC (liarning centrered classroom), teleconfrence dan sebagainya. Hal tersebut dengan memanfaatkan fasilitas seperti e-mail (surat elektronik), mobile phone, MP3Player, wibsete, blogging scarch engine dll. Lebih khusus mahasiswa bisa menggunakan laman-laman internet sebagai sumber belajar atau literasi, sebagai inovasi dalam pembelejaran pendidikan agama Islam yang bisa dimanfaatkan oleh dosen dan mahasiswa.

Inovasi adalah gagasan, tindakan atau obyek obyek yang dipersepsikan oleh seseorang pengguna lainya. Apabila ide tersebut dipandang baru oleh seseorang maka itulah inovasi. Dinyatakan juga meskipun ide tersebut lama, akan tetapi bisa dikatakan inovasi bagi orang yang baru melihat atau merasakanya (Nurhayati, 2015).

Menurut Wijaya dalam Naif (2016) menyatakan bahwa proses yang membuat suatu objek, ide atau praktek baru muncul dan diserap oleh seseorang, kelompok atau organisasi pendidikan, dapat dilihat dari model inovasinya, model inovasi ini ada tiga, yaitu : Invention (Penemuan), Devolopment (Pengembangan), dan Diffusion (Penyebaran).

Penelitian Tedi (2018) tentang inovasi pembelajaran PAI di Sekolah pada Era Distruptive Innovation didapatkan informasi jika disruptive innovation merupakan perkembangan dunia saat memasuki era revolusi industri 4.0, yang ditandai dengan masifnya perkembangan digital tehnology, artificial intelligence, big data, robotic dan perubahan yang begitu cepat yang membutuhkan banyak inovasi. Penelitian lainnya dilakukan oleh Nurhayati (2015) yang mengambil tema Inovasi pembelajaran PAI Berbasis Multiple Intelligences menyimpulkan bahwa pembelajaran berbasis multiple intelligences merupakan suatu bentuk inovasi pembelajaran yang dapat menjadi pilihan bagi guru Pendidikan Agama Islam di Indonesia. Dari beberapa penelitian diatas, mutlak dunia pendidikan terutama pembelajaran PAI ikut dipengaruhi oleh perkembangan teknologi, terutama teknologi internet dan dunia digital.

Inovasi pendidikan mutlak perlu dilakukan karena perkembangan teknologi yang memberikan kemudahan, pendidikan agama islam pun memasuki era dimana mahasiswa lebih memilih dunia digital sebagai sumber informasi dan pengetahuan baru, seperti penelitian yang dilakukan oleh Naif (2016), yang meneliti tentang Urgensi Inovasi Pendidikan Islam : Menyatukan Dikotomi Pendidikan, menyimpulkan bahwa inovasi pendidikan dilakukan untuk 
memecahkan masalah-masalah kependidikan. Jadi, inovasi adalah suatu ide, barang, metode, yang dirasakan atau diamati sebagai hal yang baru bagi hasil kelompok maupuan perorangan, baik berupa penemuan baru, atau baru ditemukan orang, untuk mencapai tujuan pendidikan atau memecahkan masalah pendidikan. Hal ini juga diperkuat oleh hasil penelitian Mustaqim (2014) dengan tema Inovasi Pendidikan Islam pengintegrasiaan Agama dan Sains, Mustaqim menyatakan bahwa inovasi pendidikan Islam pada dasarnya bersifat terbuka, demokrasi dan universal. Tetapi bersamaan dengan perkembangan maka diperlukan perbaharuan untuk memenuhi hajat untuk memperbaiki kemaslahatan kaum muslimin semua. Mahasiswa dan dosen tidak lepas dari internet, terutama medsos bagi mahasiswa, pemanfaatan teknologi informasi untuk mencari sumber atau literasi sebagai referensi dan bahan pembelajaran PAI menjadikan peneliti fokus untuk meneliti inovasi pembelajaran PAI PTU berbasis teknologi informasi di Unihaz Bengkulu.

\section{METODE PENELITIAN}

Pendekatan penelitian ini bersifat kualitatif yang ingin melihat inovasi pembelajaran Pendidikan Agama Islam (PAI). Data yang digunakan dalam penelitian ini adalah data primer dan data sekunder. Data primer diperoleh secara langsung dari sumber asli dengan teknik pengumpulan data yaitu observasi, wawancara mendalam. Data sekunder data yang didapat dari dokumentasi. Informan yang diteliti terdiri dari 5 (lima) orang mahasiswa yang sedang mengambil mata kuliah Pendidikan Agama dan 2 (dua) orang dosen yang mengajar mata kuliah Pendidikan Agama Islam (PAI).

Analisis data menggunakan teknik kualitatif deskriptif seperti keterangan dari informan dan hasil dokumentasi berkaitan dengan inovasi pembelajaran di Perguruan Tinggi Umum (PTU). Data kualitatif diinterpretasikan sesuai dengan tujuan penelitian, kemudian dilanjutkan analisis terhadap masalah yang ditemukan di lapangan, sehingga diperoleh gambaran yang jelas tentang objek yang diteliti kemudian menarik kesimpulan.

\section{HASIL DAN PEMBAHASAN}

\section{Kebijakan Mata Kuliah Pendidikan Agama Islam}

Mata kuliah Pendidikan Agama dilaksanakan di Unihaz dilaksanakan berdasarkan Undang-Undang Nomor 2 Tahun 1989 tentang sistem pendidikan Nasional yang dipakai sebagai dasar penyelenggaraan pendidikan tinggi, Pasal 39 ayat (2) menyebutkan bahwa isis kurikulum setiap jenis, jalur dan jenjang pendidikan wajib memuat: (a) Pendidikan pancasila, (b) Pendidikan Agama, dan (c) Pendidikan Kewarganegaraan yang mencakup pendidikan pendahuluan bela negara (PPBN) (Kurikulum PAI pada PTU, 2002 : iv). Didalam oprasionalnya, ketiga mata kuliah tersebut dihimpun dalam mata kuliah pengembangan kepribadian (MKPK) sebagai bagian dari kurikulum inti yang berlaku secara Nasional. 
Dengan berjalananya waktu dan perubahan-perubahan yang dihadapi dalam kehidupan di masyarakat, berbangsa dan bernegara yang berlangsung secara cepat dan kebutuhan untuk mengantisipasi perkembangan ilmu pengetahuan yang sangat pesat disertai dengan pola kehidupan menggelobal, mengharuskan Derektorat Jenderal Pendidikan Tinggi Departemen Pendidikan Nasional untuk selalu mengevaluasi kesahihan isi silabus dan GBPP Pendidikan Agama beserta proses pembelajarannya. Evaluasi isi silabus dan GBPP serta proses pembelajarannya dengan penyempurnaan untuk pemutahiran, dilaksanakan secara bertahap, berkesinambungan dan berkelanjutan oleh Derektorat Jenderal Pendidikan Tinggi.

Pada tahun 1997 silabus dan GBPP Pendidikan Agama kembali di evaluasi dan disempurnakan. Evaluasi dan penyempurnaan tersebut dengan melibatkan sebagian besar dosen-dosen pengajar mata kuliah Pendidikan Agama, kelompok kerja pembinaan Pendidikan Agama serta konsultasi dengan pimpinan beberapa perguruan tinggi. Maka berdasarkan penyempurnaan dan evaluasi silabus dan GBPP tersebut maka keluarlah Keputusan direktur Jenderal Pendidikan Tinggi Nomor : 263/DIKTI/Kep/2000 Tentang Penyempurnaan Kurikulum Inti Mata Kuliah Pengembangan Kepribadian Pendidikan Agama Pada Perguruan Tinggi di Indonesia. Pada pasal 2 berbunyi bahwa mata kuliah Pendidikan Agama adalah mata kuliah wajib untuk diambil oleh setiap mahasiswa pada perguruan tinggi untuk program Diploma/Politiknik dan program Sarjana, sesuai dengan agama yang dianutnya.

Berselang dua tahun, yaitu pada Tahun 2002 kembali dilakukan evaluasi kurikulum Pendidikan Agama. Kurikulum baru tersebut merupakan kurikulum berbasis komptensi (KBK) yang disusun oleh pakar dari kampus, bersama asosiasi profesi dan pengguna lulusan. KBK menekankan kejelasan hasil peserta didik sebagai seseorang yang kompeten dalam hal : (1) Menguasai ilmu pengetahuan dan keterampilan tertentu, (2) Menguasai pnerapan ilmu pengetahuan dan keterampilan dalam bentuk kekeryaan, (3) Menguasai sikap berkerya, dan (4) Menguasai hakekat dan kemampuan dalam kehidupan bermasyarakat dengan pilihan kekaryaan (Dirjen Dikti Diknas, 2003 : iii). Untuk acuan dalam pembelajaran berpegang kepada Keputusan Direktur Jenderal Pendidikan Tinggi Departemen Pendidikan Nasional Republik Indonesia Nomor : 38/DIKTI/Kep/ 2002 tentang Rambu-rambu pelaksanaan Mata Kuliah Pengembangan Kepribadian di Perguruan Tinggi. Dalam pasal 1 dinyatakan Visi kelompok MPK di perguruan tinggi menjadi sumber nilai dan pedoman bagi penyelenggaraan program studi dalam mengantarkan mahasiswa mengembangan kepribadiannya. Sedangkan misi kelompok MPK terdapat pada pasal 2, yaitu : Misi kelompok MPK di perguruan tinggi bertujuan untuk membantu mahasiswa agar mampu mewujudkan nilai dasar agama dan kebudayaan serta kesadaran berbangsa dan bernegara dalam menerapkan ilmu pengetahuan, teknologi dan seni yang dikuasainya denga rasa tanggung jawab kemanusiaan. 
Secara kontitusional, PAI merupakan bagian integral dalam upaya pencapaian tujuan pendidikan nasional yang bersifat sistemik dan berkelanjtan agar peserta didik menjadi orang-orang yang beriman, bertaqwa dan berakhlak mulia, sebagaimana amanat yang tertuang dalam Undang-Undang Nomor 20 Tahun 2003 tentang sistem pendidikan nasional bab II Pasal 3 yang menyatakan bahwa, "Pendidikan nasional befungsi mengembangkan kema[puan dan membentuk watak serta peradaban bangsa yang bermartabat dalam rangka mencerdaskan bangsa, bertujuan untuk berkembangnya potensi peserta didik agar menjadi manusia yang beriman dan bertaqwa kepada tuhan yang Maha Esa, berakhlak mulia, sehat, berilmu, cakap, kreatif, mandiri dan menjadi warganegara yang demokratis serta bertanggung jawab".

Undang-Undang di atas secara tegas bahwa tujuan pendidikan nasional diarahkan pada pembentukan empat aspek, yaitu : aspek religius, aspek moral, aspek intelektual, dan aspek kebangsaan. Kesemua aspek itu diwujudkan dalam rangka membentuk manusia yang utuh dan paripurna (insan kamil). Pendidikan Agama mengambil peran utama dalam membina aspek riligius dan aspek moralitas.

Selanjunya dalam pasal 52 Undang-Undang Nomor 12 Tahun 2012 Tentang Pendidikan Tinggi kembali dikukuhkan wajib adanya mata kuliah pendidikan agama, yang sudah dapat dipastikan merupakan suatu identitas utuh psikopedagogis/andragogis dalam kurikulum program diploma dan sarjana. Secara konseptual dan paradigmatik, tujuan akhir atau capaian pembelajaran (learning outcomes) pendidikan agama islam adalah terbentuknya kepribadian mahasiswa secara utuh (kaffah) dengan menjadikan ajaran sebagai landasan berfikir, bersikap dan berprilaku dalam pengembangan keilmuan dan profesinya (Kemenristik Dikti, 2016).

\section{Inovasi Pembelajaran Pendidikan Agama Islam Berbasis Teknologi Informasi}

Kepribadian yang utuh pada pasal 52 Undang-Undang Nomor 12 Tahun 2012, yang dapat terwujud apabila pada diri mahasiswa tertanan iman dan taqwa kepada Allah SWT. Dari bunyi pasal tersebut artinya kepribadian yang utuh hanya dapat diwujudkan apabila pada diri setiap mahasiswa tertanaman iman dan taqwa kepada Allah Swt. Namun perlu dicatan bahwa keimanan dan ketaqwaan, hanya akan terwujud apabila ditopang dengan pengembangan elemen-elemnenya, yaitu: wawasan/pengetahuan tentang islam (Islamic knowledge), sikap keberagamaan (Religion dispositions), keterampilan menjalankan ajaran islam (Islamic skills), kometmen terhadap islam ( Islamic committment), kepercayaan diri sebagai seorang muslim (Moslem confidence), dan kecakapan dalam melaksanakan ajran agama (Islamic competence).

Maka untuk mewujudkan sangat ditentukan dengan pembelajaran pendidikan agama di perguruan tinggi itu sendiri. Peran dosen sebagai pendidik 
dan pengajar sangat menentukan keberhasilan visi dan misi pendidikan agama. Supaya pembelajaran tidak jenuh dan membosankan inovasi dosen dalam pembelajaran sangat menetentukan. Baik itu dalam metode, literasi maupun yang lainnya.

Berdasarkan wawancara dengan beberapa mahasiswa yang mengambil mata kuliah Pendidikan Agama Islam dan dua orang dosen Agama di Universitas Prof. Dr. Hazairin, SH Bengkulu. Untuk melihat bagaimana inovasi yang pembelajaran PAI yang dilakukan oleh dosen dan mahasiswa dalam memanfaatkan teknologi informasi guna mewujudkan visi dan misi serta tujuan pendidikan agama islam di perguruan tinggi, yaitu : "terbentuknya mahasiswa yang memiliki kepribadian utuh ( $k a f f a h)$ dengan menjadikan ajaran islam sebagai landasan berfikir dan berprilaku dalam pengembangan kepribadian, keilmuan dan profsinya.

Melalui pengamatan yang dilakukan bahwa hampir semua mahasiswa maupun dosen di Unihaz telah memiliki aplikasi dan akun medsos seperti Facebook, Blok, Website, instragram,Twitter dan aplikasi lainnya, dan hampir semua baik mahasiswa maupun dosen mendapat sumber pembelajaran yang diperoleh dari internet seperti jurnal, dalam mengerjakan makalah, tugas dan karya-karya lainnya. Kebanyakan sumber diperoleh dari internet dan bahkan dosen sudah memperbolehkan menjadikan internet sebagai sumber pembelajaran atau menjadikan internet sebagai sumber informasi atau refrensi, karena informasi yang diperoleh dari internet lebih update, kekinian atau sangat relevan dengan permasalah yang terjadi pada saat ini, selain itu juga sumber pembelajaran yang didapat dari internet lebih mudah di dapat, kapan saja dan dimana saja.

Berdasarkan wawancara dengan dosen Pendidikan Agama Islam (PAI) baik Bapak Samsudin maupun Ibu Asmara Yumarni, guna memperoleh data untuk mengetahui inovasi pembelajaran PAI dengan memanfaatkan teknologi informasi sebagai sumber dan media pembelajaran, diperoleh informasi sebagai berikut, yaitu:

Pertama, Dosen menginstruksikan untuk menggunakan jurnal-jurnal online atau media internet sebagai sumber dalam mencari tugas. Dari hasil wawancara dengan beberapa mahasiswa (Intan, Eza dan lain-lain) ia menceritakan bahwa, dalam proses perkulihan dosen, banyak memberikan tugas-tugas baik berupa makalah, resume dan lain sebagainya, baik dosen mata kuliah jurusan maupun mata kuliah umum, seperti Pendidikan Agama Islam (PAI). Tugas-tugas yang diberikan tersebut tentunya harus dengan refrensi sebagai persyaratan sebuah tulisan ilmiah, dalam refrensi tersebut dosen menginstruksikan untuk menggunakan informasi yang update dan bisa dipertanggung jawabkan. Bahkan dosen menginstruksikan jurnal-jurnal tertentu untuk dijadikan sumber atau refrensi.Jurnal-jurnal tersebut dapat diakses di laman-laman internetuntuk di dounlod dan ditulis di daftar pustakapada makalah-makalah yang sudah dibuat. 
Data tersebut dikonfirmasi kepada dosen yang mengajar Pendidikan Agama Islam (PAI) yaitu Bapak Samsudin dan Ibu Asmara Yumarni, maka beliau menjawab, memang benar kami dalam memberikan tugas kepada mahasiswa baik berupa makalah maupun resume atau yang lainnya, kami menjadikan jurnal-jurnal tertentu sebagai refrensi dan jurnal-jurnal tersebut harus ada dalam daftar pustaka, dan untuk mendapatkan jurnal tersebut mahasiswa harus mendounlod di lamanlaman internet, karena semua jurnal sudah oneline semua.

Kedua, Tugas pada materi tententu dibuat dalam bentuk video. Dari wawancara dengan beberapa mahasiswa, mereka menceritakan bahwa pada beberapa materi perkuliahan kami diberikan tugas untuk membuat video sebagai ungkapan bahwa kami seorang mahasiswa yang bertuhan. Dosen memberikan sebuah cerita sebagai langkah dalam pembuatan video. Cerita tersebut seperti, “ anda duduk ditepi pantai melihat ombak bergelombang ditiup angin sepoi-sepoi, apa yang kamu pikirkan". Dalam melihat data ini peneliti juga melakukan wawacara dengan alumni dan dosen, mereka juga mendukung jawaban tersebut, mereka mengatakan "kami ditugaskan membuat sebuah video oleh dosen Pendidikan Agama Islam (PAI) yang sebelumnya kami dijelaskan dulu tentang bagaiman manusia bertuhan dan dikaitkan dengan tugas manusia dimuka bumi.

Ketiga, pemberian tugas melalui WhatsApp group dan Pengiriman tugas mahasiswa melalui e-mail dan WhatsApp. Dalam penelitian ini, mahasiswa menjelaskan setelah pembelajaran di kelas kami diberikan tugas-tugas, seperti makalah yang akan dipersentasikan pada pertemuan selanjutnya, materi yang harus diresume untuk dijelaskan di depan kelas secara individu dan beberapa materi ditugaskan dengan pembuatan vedio, dengan harapan tingkat pemahaman kami mahasiswa lebih lekat dalam ingatan. Vedio-vedio tersebut mahasiswa diminta mengirimkan atau mengumpulkan kepada dosen dengan melalui e-mail atau WhatsApp, yang nantinya akan menjadi penilaian bagi hasil kerja mahasiswa.

Peneliti juga melakukan wawancara kepada dosen untuk menanyakan hal tersebut di atas, maka dosen menjawab sesuai dengan apa yang sudah disampaikan oleh mahasiswa sebelumnya. Kami memang meberikan tugas-tugas, baik itu makalah, resume atau vedio-vedio kepada mahasiswa, dan mereka akan mengumpulkan pada waktu yang telah ditentukan melalui e-mail atau WhatsApp, yang tugas tersebut akan menjadi indikator penilaian bagi mahasiswa dalam mendapatkan nilai akhir nanti.

\section{Inovasi Pembelajaran Pendidikan Agama Islam dilihat dari Kajian Tentang Inovasi Pendidikan}

Dari analisa penulis, dilihat dari kajian inovasi, maka inovasi yag dilakukan dalam pembelajaran pendidikan agama islam di Universitas Prof. Dr. Hazairin, SH Bengkulu sudah termasuk kedalam pengertian inovasi, baik menggunakan jurnal-jurnal one line atau media internet sebagai refrensi atau 
literasi, pembuatan vedio maupun pembagian tugas dan pengumpulannya dengan memanfaatkan teknologi informasi. Hal ini bisa dilihat dari pengertian inovasi dari beberapa pakar, yaitu sebagaimana dikemukan oleh Rogers dalam (Titi Nurhayati, 2015) inovasi adalah gagasan, tindakan, atau objek yang dipersepsikan baru oleh seseorang atau satuan pengguna lainnya. Lebih lanjut Rogers menyatakan bahwa tidak dipersoalkan apakah suatu ide, praktik atau objek tersebut secara baru atau tidak. Apabila ide tersebut dipandang baru oleh seseorang maka itulah inovasi.

Hal senada diungkap Kemendiknas dalam buku modul Konsep Dasar Kewirausahaan, Inovasi adalah sesuatu yang berkenan dengan barang, jasa atau ide yang dirasakan baru oleh seseorang. Meskipun ide tersebut telah lama ada tetapi ini dapat dikatakan suatu inovasi bagi orang yang baru melihat atau merasakannya.

Dari dua definisi tersebut menyatakan bahwa inovasi adalah suatu ide, halhal yang praktis, metode, cara, barang-barang buatan manusia, yang diamati dan dirasakan sebagai suatu yang baru baru seorang atau kelompok orang (masyarakar). Hal yang baru tersebut bisa berupa hasil invensi atau discoveri, yang digunakan untuk mencapai tujuan tertentu atau memecahkan masalah. Yang sudah dilakukan dalam pembelajarn pendidikan agama islam di Unihaz adalah mencoba sesuatu yang baru dalam mempermudah proses pembelajaran dengan memanfaatkan teknologi informasi sebagai literasi, pembagian dan pengumpulan tugas.

\section{Dilihat Dari Inovasi Pendidikan}

Apabila dilihat dari inovasi pendidikan, maka inovasi yang dilakukan dalam pembelajaran pendidikan agama islam di Unihaz, termasuk kedalam Inovasi pendidikan. Pertama, kurikulum update mengacu kepada kurikulum Nasional, kedua, pemanfaatan teknologi informasi dalam proses pembelajaran, baik menggunakan jurnal-jurnal one line atau media internet sebagai refrensi atau literasi, pembuatan vedio mterus mengikuti aupun pembagian tugas dan pengumpulannya. Hal tersebut dapat dilihat dari pengertian inovasi pendidikan adalah sebuah upaya untuk meningkatkan kemampuan dari berbagai sumber komponen pendidikan, seperti : a) Tenaga kependidikan, b) Sarana dan prasarana pendidikan, c) Sistem dan konsep dalam pelaksanaan kegiatan pendidikan (Naif, 2016). Artinya keseluruhan sistem yang terkait dengan pendidikan perlu untuk ditingkatkan agar semua tujuan yang direncanakan dapat dicapai dengan sebaikbaiknya.

Hal senada dukung juga dengan pendapat Hasbullah dalam Naif, (2016), Kompleknya permasalahan pendidikan yang dialami oleh pola pelaksanaan di negeri ini, menuntut kita untuk merespon untuk melakukan suatu kegiatan tindakan prefentif, persuasive dan inovatif. Walau sesuatu yang baru belum tentu baik, artinya adanya inovasi belum tentu inovatif, kreatif, apalagi relevansinya 
dengan situasi dan kondisi, sehingga dapat dikatakan bahwa inovasi pendidikan dilakukan sebagai suatu problem solving dari berbagai macam problematika pendidikan yang dihadapi. Secara sederhana, masalah pendidikan yang harus menuntut suatu inovasi.

Kemajuan ilmu pengetahuan dan teknologi yang dicapai barat telah mengeser pandangan hidup manusia serta melahirkan teman-teman baru, seperti nasionalisme dan pendidikan. Pendidikan merupakan sarana yang paling penting bukan hanya sebagai wahana koservasi dalam arti tempat pemeliharaan, pelestarian, penanaman, dan pewarisan nilai-nilai dari tradisi suatu masyarakat, tetapi juga sebagai sarana pembaharuan/inovasi yang dapat menciptakan, mengembangkan dan mentraspormasikan umat kearah pembentukan budaya baru.

Oleh karena itu inovasi-invasi pendidikan tersebut sebagai arah baru dalam dunia kependidikan yang berfungsi sebagai alternatif memecahkan masalah pendidikan yang belum dapat diatasi dengan cara konvensional secara tuntas. Secara lebih rinci tentang maksud-maksud diadakannya inovasi pendidikan ini adalah sebagai berikut : (1) Pembaruan pendidikan sebagai tanggapan baru terhadap masalahpendidikan. Majunya bidang tekhnologi dan komunikasi sekarang ini dapat memberikan pengaruh positif terhadap kemajuan di bidang lain, termasuk dalam dunia pendidikan. Tugas inovator pendidikan yang terutama adalah memecahkan masalah yang dijumpai dalam dunia pendidikan, baik dengan cara yang konvensional maupun dengan cara yang inovatif. Inovasi atau pembaruan pendidikan juga merupakan suatu tanggapan baru terhadap masalah kependidikanyang nyata dihadapi. Titik pangkal pembaharuan pendidikan adalah masalah pendidikan yang aktual, yang secara sistematis akan dipecahkan dengan cara inovatif. (2) inovasi pendidikan sebagai upaya untuk mengembangkan pendekatan yang lebih efektif dan ekonomis. Inovasi pendidikan dilakukan dalam upaya "problem solping" yang dihadapi dunia pendidikan yang selalu dinamis dan berkembang. Menurut Hasbullah dalam Naif (2016) Adapun sifat pendekatan yang diperlukan untuk memecahkan untuk pemecahhan masalah pendidikan yang konpleks dan berkembang itu harus berorientasi kepada hal-hal yang efektif dan murah, serta pekah terhadap timbulnya masalah baru dalam pendidikan.

\section{Dilihat dari Model Inovasi Pendidikan}

Menurut penulis dalam penelitian ini, apabila dilihat dari model inovasi, maka apa yang sudah dilakukan dalam pembelajaran pendidikan agama islam di Unihaz, sudah dikatakan masuk kedalam model inovasi yang ada, yaitu :penemuan, pengembangan dan penyebaran. Disaat kita bicara inovasi pendidikan itu sendiri. Pembaharuan dalam pendidikan ini menunjuk kepada suatu proses yang membuat suatu obyek, ide, atau praktek baru yang muncul untuk kemudian diserap oleh seseorang, kelompok, organisasi pendidikan. Model inovasi pendidikan dapat dilihat dari beberapa tahapan, yang digambarkan dengan suatu kontinum sebagai beriku : 1). Invention (Penemuan) Invention meliputi 
penemuan atau penciptaan tentang suatu hal yang baru. Akan tetapi pembaharuan yang terjadi dalam pendidikan terkadang menggambarkan suatu hasil yang sangat berbedah dengtan yang terjadisebelumnya. Tempat terjadinya invention biasanya di dalam maupun di luar lembaga pendidikan (sekolah/perguruan tinggi) kebanyakan pembaharuan dari tipe hardware berasal dari luar lembaga pendidikan atau perguruan tinggitersebut. Sebaliknya, banyak "Invention" terjadi di dalam lembaga pendidikan atau perguruan tinggi ketika para dosen berupaya untuk mengubah situasi atau menciptaka cara baru untuk memecahkan cara lama. 2). Devolopment (Pengembangan) Pembaharuan biasanya harus mengalami suatu pengembangan, dan belum bisa masuk ke dalam dimensi skala besar. "Devolopment" sering sekali bergandengan dengan riset sehingga prosedur resarch dan devolopment meliputi berbagai aktivitas, antara lain riset dasar, seperti pencarian dan pengujian teori-teori belajar. Riset ini mengetengahkan proses pengembangan kurikulum oleh para tim ahli penulis program kurikulum, lembaga pendidikan atau perguruan tinggi tempat bahan disiapkan untuk diujicobakan. Dan desain riset valuatif dibuat untuk menilai keefektifan berbagai pebaharua kurikulum. 3). Diffusion (Penyebaran) Konsep diffusion sering kali digunakn secara sinonim dengan konsep dissemination, akan tetapi disini diberikan dengan konotasi yang berbedah. Depinisi diffusion menurut Roger adalah "persebaran suatu ide baru dari sumber inventationnya kepada pemakai atau penyerap yang terakhir". Menurut Cece Wijaya dalam Naif (2016) Kalau istilah diffusion adalah netral dan betul memaksudkan persebaran suatu pembaharuan, dissemination digunakan disini untuk menunjukan suatu pola dipusi yang terencana, yang didalamnya beberapa biro (agency) mengambil langka khusus untuk menjamin suatu pembaharuan akan mencapai jumlah paling banyak.

\section{Tantangan dan Inovasi Pembelajaran PAI di PTU Berbasis Teknologi Informasi}

Dalam penelitian ini penulis menganalisis bahwa, inovasi pembelajarn pendidikan agama islam di Unihaz sudah termasuk kepeda pembelajaran berbasis teknologi informasi. Hal itu dapat dilihat dari cara membagi tugas, mengumpulkan tugas dan lirasi atau sumber-eumber yang digunakan dalam proses belajar mengajar. Hal itu bisa dilihat dari ciri-ciri zaman teknologi informasi dan komunikasi ciri-ciri tersebut adalah, sebagai berikut : (1) Daya muat untuk mengumpulkan menyimpan, memanipulasikan dan menyajikan informasi berkembang pesat. (2) Kecepatan penyajian informasi sangat meningkat. (3) Keragaman pilihan informasig tersedia begitu banyak. (4) Biaya perolehan informasi menjadi murah dan bias instran. (5) Distribusi informasi yang semakin cepat dan menjadi luas jangkauannya. Kemajuan teknologi informasi dan komunikasi telah mempermudah pembelajaran PAI di Unihaz terutama dalam pencarian bahan atau literasi, pengumpulan tugas dan pembagian tugas mahasiswa 
dan pengumpulannya.

Perkembangan teknologi informasi dan komunikasi senyatanya telah memberikan sumbangan signifikat dan mendorong terjadinya perubahan dalam dunia pendidikan maupun pembelajaran. Dosen bukan lagi satu-satunya sumber dalam proses pembelajaran. Menurut penulis apa yang dilakukan dalam pembelajaran Pendidikan Agama Islam di Unihaz termasuk kelompok revolusi keempat, yaitu, terjadi saat teknologi komunikasi berkembang sangat pesat dimana semua bahan, proses dan bentuk pendidikan dapat ditransfer melalui teknologi. Hal ini sejalan dengan pendapat yang mengatakan, Menurut Eric Ashby dalam Tedi Priatna (2018) menulis tentang perkembangan ini dalam empat revolusi dramatis. Revolusi pertama, terjadi pada saat masyarakat memberikan wewenang dan kepercayaan pendidikan kepada orang tertentu saja hingga timbul profesi dosen. Revolusi kedua, terjadi saat digunakan tulisan sebagai sumber belajar di perguruan tinggi melalui buku refrensi. Revolusi ketiga, terjadi saat ditemukan mesin cetak yang mengakibatkan pendidikan lebih berbasis pada sumber buku yang beragam dan marak tersedia. Revolusi keempat, terjadi saat teknologi komunikasi berkembang sangat pesat dimana semua bahan, proses dan bentuk pendidikan dapat ditransfer melalui teknologi.

Perkembangan teknologi informasi dan komunikasi telah membawah revolusi dalam berbagai bidang kehidupan, dan dunia pendidikan. Pendidikan merupakan faktor kunci dalam peningkatan kualitas sumber daya manusia. Pengembangan dan implementasi kurikulum saat ini yang mengintegrasikan teknologi informasi dalam pemebelajaran mengharsukan dosen dan mahasiswa menguasai teknologi. Mahasiswa dan dosen aktif terlibat dalam proses pembelajaran dengan memanfaatkan teknologi, baik sebagai sumber, media maupun sebagai alat pembelajaran. Paradigma pemebelajaran telah bergeser menuju pembelajaran berbasis digital.

Model pembelajaran berkembang dalam bentuk pembelajaran elektronik (e-liarning), buku elektronik (e-book), kelas online, diskusi online, pembelajaran berbasis komputer. Penggunaan papan tulis spidol, berganti dengan menggunakan media notebook, LCD, Projektor dan sebagainya. Printer material buku sumber, mudol dan lembar kerja mahasiswa menjadi e-book, digital library, youtobe dan laman-laman internet. Pembelajaran konvensional cerama di depan kelas berganti dengan model-model baru berbasis IT seperti CBT (computer based test), CBI (computer based instruction), distance liarning, LCC (liarnercentrered classroom), teleconfrence dan sebagainya, dengan memanfaatkan fasilitas seperti e-mail (surat elektronik) mobile phone, MP3 Player, wibsete, blogging, search engine dll.

Keterampilan dalam penguasaan teknologi merupakan kecakapan hidup (lifeskill) yang harus dimiliki oleh dosen dan mahasiswa. Jika tidak, mahasiswa akan mengalami kesulitan bersaing. Peran seorang dosen sangat krusial dan signifikan dalam hal ini, oleh sebab itu dosen harus membekali diri dengan 
menguasai teknologi informasi. Dengan dosen yang trampil dan selalu meningkatkan kompetensinya maka akan menjadikan mahasiswa yang cakap dan trampil pula tentunya.

Sebagai masukan ada beberapa rekomendasi yang dapat penulis mengidentifikasi beberapa hal yang dapat dilakukan dalam inovasi pembelajaran pendidikan agama islam di Unihaz dan perguruan tinggi lainya.Pertama, perubahan orientasi pembelajaran PAI. Pembelajaran PAI di PTU dianggap kurang bisa mengubah pengetahuan agama yang kognitif menjadi bermakna dan bernilai yang perlu diintegrasikan dalam diri mahasiswa. PAI belum memilki relevansi memadai dengan realitas sosial, sehingga mahasiswa kurang menghayati nilai-nilai agama. Oleh sebab itu diperlukan perubahan paradigma pembelajaran PAI di PTU yang bukan orientasi kognitif semata, tetapi juga psikomotor, afektif dan yang paling mendesak adalah aspek sikap dan prilaku keberagamaan.Kedua, pengembangan alternatif pembelajaran PAI di PTU. Model pembelajaran harus diintegrasikan dengan keseluruhan sistem pendidikan. Seoptimal apapun pembelajaran PAI dengan hanya mengandalkaan jam pelajaran di dalam kelas, maka masih akan menyisakan ruang kosong, terutama pada sasaran pembelajaranaspek sikap dan tingkah laku.

Hal ini sejalan dengan hasil penelitian yang diungkapkan di atas yaitu : (1) bahwa dosen Pendidikan Agama islam (PAI) sudah memanfaatkan Jurnal-jurnal oneline untuk dijadikan refrensi dalm pembuatan tugas-tugas baik berupa makalah, maupun resume. (2) Tugas pada materi tententu dibuat dalam bentuk vedio. (3) Pemberian tugas melalui WhatsApp group dan Pengiriman tugas mahasiswa melalui e-mail dan WhatsApp.

Laman internet yang berhubungan dengan sumber pembelajaran memungkinkan materi pembelajaran disajikan lebih variatif dan menarik. Ketersediaan Al-Qur'an digital, kitab-kitab hadits digital, kitab-kitab tafsir digital dan berbagai sumber khazanah Islam, sangat disayangkan jika para dosen PAI di PTU belum berinovasi sehingga belum memanfaatkannya sebagai media pembelajaran.

Untuk mencapai visi, misi dan tujuanPAI di PTU diperlukan proses yang koheren dan utuh yang dapat mengembangkan seluruh kompetensi beragama mahasiswa berdasarkan Kompetensi Inti (KI) dan Kompetensi Dasar (KD) yang berfungsi sebagai elemen pengorganisasian (organizing element) kurikulum MKWU PAI di PTU. Dalam konteks pendidikan tinggi, proses pendidikan ini dimaksudkan untuk mengembangka seluruh potensi positif mahasiswa dalam pengembangan keimana, ketaqwaan, dan akhlak mulia baik secara pribadi maupun secara kolektif yang sistemik dalam pewujudan Tridarma Perguruan Tinggi (pendidikan, penelitian dan pengabdian kepada masyarakat) yang diperkuat dengan penciptaan lingkungan yang religius.

Perguruan tinggi dalam hal ini dosen PAI di PTU harus mulai mengajarkan mahasiswa bagaiman cara belajar, befikir kritis, didorong untuk 
menjalani profesi baru dimasa depan, kemampuan untuk beradaptasi terhadap perubahan dan yang lebih penting lagi diajarkan sesuatu yang tidak bisa dilakukan oleh teknologi, seperti berfikir kreatif, inovatif kerjasama tim dan terkait dengan budaya. Dosen dan orang tua harus menekankan pentingnya pendidikan karakter dan soft skill agar kelak mahasiswa kita mampu menjadi pribadi yang mandiri dan mempunyai kehidupan yang lebih baik.

Dalam halini dosen memang memegang peran kunci mengarahkan memfasilitasi dan mendampingi mahasiswa dalam belajar. Teknologi informasi harus dimanfaatkan dosen untuk membantu peran dosen tersebut. George Couros mengemukakan "technology will never replace great lecturer but technology in the hands of great lecturers is transformational" artinya teknologi tidak akan pernah menggantikan dosen yang hebat tetapi teknologi di tangan dosen yang hebat itu ditransformasional.

\section{SIMPULAN}

Simpulan penelitian ini adalah: 1) Mata Kuliah Pendidikan Agama adalah mata kuliah wajib nasional yang mengacu kepada Undang-undang Nomor 12 Tahun 2012 Tentang Pendidikan Tinggi, yang tujuan akhir atau capaian pembelajaran (learning outcomes) pendidikan agama islam adalah terbentuknya kepribadian mahasiswa secara utuh (kaffah) dengan menjadikan ajaran sebagai landasan berfikir, bersikap dan berprilaku dalam pengembangan keilmuan dan profesinya; 2) Inovasi pendidikan yang dilakukan adalah termasuk kedalam tiga model inovasi yaitu Invention (Penemuan), Devolopment (Pengembangan) dan Diffusion (Penyebaran), maka yang dominan adalah Devolopment (Pengembangan). Pembaharuan biasanya harus mengalami suatu pengembangan, dan belum bisa masuk ke dalam dimensi skala besar; 3). Inovasi dilakukan untuk dapat memecahkan masalah-masalah kependidikan, adanya perubahan orientasi pembelajaran dan pengembangan alternatif atau inovasi pembelajaran Pendidikan Agama Islam (PAI)

Penggunaan teknologi informasi dalam inovasi pembelajaran PAI di PTU harus dikembangkan dan ditempatkan menjadi sumber bahan ajar, referensi belajar, dan sumber informasi. Model pembelajaran dikembangkan dalam bentuk pembelajaran elektronik (e-learning), buku elektronik (e-book). Penggunaan media sosial dalam pembelajaran juga harus menjadi alternatif. Termasuk digunakan dan dimanfaatkannya media sosial untuk pengembangan atau inovasi pembelajaran PAI di PTU. 


\section{DAFTAR PUSTAKA}

Kementerian Riset. (2016) Teknologi dan Pendidikan Tinggi Republik Indonesia, Pendidikan Agama Islam Untuk Perguruan Tinggi. Derektorat Jenderal Pembelajaran dan Kemahasiswaan Kementerian Riset, Teknologi dan Pendidikan Tinggi RI.

Munawiroh. (2017). Relevansi Buku Pendidikan Agama Islam Terbitan Yamiba Dengan Kurikulum. Edukasi: Jurnal Penelitian Pendidikan Agama dan Keagamaan, 207-221

Mustaqim. (2014). Inovasi Pendidikan Islam:Pengintegrasian Agama dan Sains. E-Jurnal Pendidikan dan Kegamaan IAIN Ngawi, 1-13

Naif. (2016). Urgensi Inovasi Pendidikan Islam: Menyatukan Dikotomi Pendidikan. Jurnal Kordinat, 15(1); 1-16.

Nurhayati, T. (2015). Inovasi Pembelajaran PAI Berbasis Multiple Intelligences. Jurnal Pendidikan Agama Islam. Jurnal Pendidikan Agama Islam. 3(1); 23-56

Priatna, T. (2018). Inovasi Pembelajaran PAI di Sekolah Pada Era Disruptive Innovation. Jurnal Tatsqif. Jurnal Pemikiran dan Penelitian Pendidikan $16(2) ; 16-41$ 